\title{
Evaluasi Tata Kelola TI Menggunakan Framework COBIT 5 Studi Kasus STMIK Primakara
}

\author{
Marciano Risky Fradinata ${ }^{1}$, I Gede Juliana Eka Putra ${ }^{2}$, I Nyoman Yudi Anggara Wijaya ${ }^{3}$ \\ Program Studi Sistem Informasi \\ Program Studi Teknik Informatika \\ STIMIK Primakara \\ Denpasar, Indonesia \\ Email: marcianoriskyf@gmail.com ${ }^{1}$, gedejep@ primakara.ac.id ${ }^{2}$, inyomanyudi@gmail.com³
}

\begin{abstract}
STMIK Primakara is a Technopreneurship campus who have a vision to produce IT Scholar with entrepreneurial mentality. However, to achieve that, STMIK Primakara need to manage the IT Government to support the academics and non-academics environment around the students until graduates are controlled by department of IT Development and Implementation (PPTI).

The researcher will evaluates the capability level of IT Governance in STMIK Primakara and provide recommendations for the gap between the performance in domain process APO03, APO04, and BAI01 using quantitative and qualitative methods. Moreover, the researcher will use survey, interview, and document studies for the data required. The results of this research shows the average of capability level in domain process APO03, APO04, and BAIO1 are partially achieved. Therefore, to fill the gap between STMIK Primakara current capability level and expected capability level, recommendation have been given by the researcher to create an improvement regarding to STMIK Primakara IT Governance.
\end{abstract}

\section{Keywords-IT Governance, COBIT 5, STMIK Primakara}

\section{PENDAHULUAN}

Perkembangan teknologi informasi yang sangat pesat memang tidak dapat dihindari. Kebutuhan akan teknologi saat ini, baik di perusahaan maupun organisasi, sangat penting demi menunjang dan membantu mengefisiensikan serta efektivitas terhadap kegiatan yang mereka lakukan. Untuk mencapai efisiensi dan efektivitas tersebut, dibutuhkan suatu pengelolaan teknologi informasi yang baik dan benar guna membantu perusahaan atau organisasi tersebut dapat mencapai tujuannya serta dapat mengelola sumber daya yang ada dengan baik. "Teknologi informasi adalah seperangkat alat yang membantu pekerjaan dengan informasi serta melakukan tugas-tugas yang berhubungan dengan pemrosesan informasi [1]."

Tata kelola teknologi informasi adalah prosedur dan kumpulan proses yang bertujuan untuk memastikan kesesuaian penerapan IT dengan dukungannya terhadap pencapaian tujuan organisasi, dengan cara mengoptimalkan keuntungan yang ditawarkan oleh IT, mengontrol penggunaan terhadap sumber daya IT dan mengelola resiko - resiko terkait IT. Tata kelola TI diperlukan guna mengoptimalkan penggunaan sumber daya yang ada, membantu menjembatani gap antara kebutuhan kontrol dan permasalahan teknis serta resiko yang akan terjadi, bisa juga dapat memberikan masukan berupa rekomendasi yang dapat digunakan untuk perbaikan pengelolaan di masa yang akan datang, selain melakukan evaluasi terhadap pengelolaan yang sudah berjalan.

STMIK Primakara merupakan kampus IT yang berada di Denpasar, Bali, dimana STMIK Primakara sudah menerapkan teknologi informasi dalam setiap aspek, mulai dari belajar mengajar, sistem informasi akademik, keuangan, sampai kepada manajemen. Setiap aspek yang ada pun sudah terkelola dengan cukup baik. Sebagai contoh, pada proses penerimaan mahasiswa baru di STMIK Primakara, calon mahasiswa baru tidak perlu datang ke kampus untuk melengkapi data persyaratan, sudah cukup dengan mendaftar secara online. Hal ini tentunya sangat membantu baik pihak calon mahasiswa baru maupun divisi yang ditugaskan untuk menerima data-data dari mahasiswa baru.

Berdasarkan informasi yang diperoleh peneliti dari beberapa civitas akademika STMIK Primakara, sistem informasi yang ada di STMIK Primakara mulai dari proses 
e-ISSN: 2685-7006 | p-ISSN: $2252-9063$

Kumpulan Artikel Mahasiswa Pendidikan Teknik Informatika

(KARMAPATI)

Volume 10, Nomor 1, Tahun 2021

penerimaan mahasiswa baru (hulu) hingga proses kelulusan dan pascasarjana (hilir) telah dibangun dan diimplementasikan untuk membantu mahasiswa menempuh jenjang pendidikan S1. Namun, layanan sistem informasi yang digunakan oleh STMIK Primakara untuk menunjang kepentingan akademik mahasiswa masih belum optimal. Selain itu, informasi yang didapatkan berdasarkan hasil wawancara peneliti kepada beberapa staf STMIK Primakara, terdapatnya gap dari proses hulu ke hilir, dimana yang memegang peranan penting dalam proses ini adalah divisi marketing, WAKA I bidang akademik, WAKA II bidang sumber daya dan keuangan serta WAKA III bidang kemahasiswaan. Gap yang dimaksud adalah pada sistem pendataan mulai dari data mahasiswa baru hingga data mahasiswa yang sudah lulus.

Di dalam pembangunan sistem informasi yang ada di STMIK Primakara, divisi yang bertanggung jawab adalah PPTI (Pengembangan dan Penerapan Teknologi Informasi). Tugas dari PPTI adalah membangun sistem informasi di STMIK Primakara sesuai dengan Renstra dan Masterplan yang telah dibuat oleh jajaran manajemen STMIK Primakara (APO03). Dalam proses pembangunan sistem informasi yang mendukung kegiatan di STMIK Primakara, divisi PPTI bertanggung jawab untuk merancang, membangun, mengimplementasikan dan memelihara sistem informasi (APO04 dan BAI01). Dengan melakukan studi dokumen yang ada di STMIK Primakara, peneliti menemukan bahwa terdapat beberapa sistem informasi yang masih belum berjalan sebagaimana mestinya.

Berdasarkan pemaparan diatas, maka dalam penelitian ini, evaluasi terhadap tata kelola TI dengan menggunakan framework COBIT 5 dilakukan untuk mengetahui tingkat kapabilitas pada proses tata kelola TI yang ada di STMIK Primakara dalam mengelola kebutuhan sistem informasi mahasiswa, mulai dari pendaftaran hingga lulus. Hasil penelitian ini nantinya dapat dijadikan saran atau acuan bagi pengembangan tata kelola TI dalam membangun sistem informasi yang lebih efektif dan efisien sehingga memenuhi standar IT Governance yang berkesinambungan. istem informasi yang diterapkan pada sektor pendidikan,

\section{TINJAUAN PUSTAKA}

\section{A. Tata Kelola TI}

Tata kelola TI adalah proses yang digunakan untuk memantau dan mengendalikan keputusan kapabilitas teknologi informasi untuk memastikan pengiriman nilai kepada pemangku kepentingan utama dalam suatu organisasi[2]. Tata kelola TI adalah konsep luas yang berpusat pada setiap departemen dan lingkungan IT yang membentuk/memberikan nilai bisnis terhadap perusahaan tersebut[2]. Menurut IT
Governance Institute (ISACA), tata kelola TI adalah kepemimpinan, struktur, dan proses organisasi untuk memastikan teknologi informasi dapat mempertahankan, memperluas strategi, dan mencapai tujuan organisasi[2].

Tujuan utama dari tata kelola TI adalah untuk menyelaraskan setiap proses bisnis organisasi dengan teknologi informasi yang ada saat ini, maksudnya adalah dengan adanya struktur dan proses yang diperlukan dalam investasi teknologi informasi, pihak manajemen dapat memastikan teknologi informasi yang diterapkan sesuai dengan strategi bisnis yang ada[3].

\section{B. COBIT 5}

Control Objectives for Information and related Technology (COBIT) adalah framework bagi pengelolaan teknologi informasi (IT Management) yang secara lengkap terdiri dari: executive summary, framework, control objectives, audit guidelines, implementation tool serta management guidelines yang sangat berguna untuk proses sistem informasi strategis. COBIT 5 dirancang dengan 34 control objective yang tercermin di dalam 1 area proses tata kelola dan 4 area proses manajemen. Kelima domain area proses tersebut terdiri dari:

a) Evaluate, Direct, and Monitor (EDM), domain ini berfungsi untuk menentukan praktik-praktik dalam pengelolaan Teknologi Informasi yang mencakup evaluasi, pengarahan, dan monitoring.

b) Align, Plan, and Organize (APO), domain ini mencakup sinergisasi, optimasi, penyaluran, dan pengaturan agar Teknologi Informasi dapat mengoptimalkan pencapaian tujuan bisnis.

c) Build, Acquire, and Implement (BAI), domain ini mencakup pembangunan, pengumpulan, dan pengimplementasian sistem yang bertujuan untuk mendukung proses bisnis.

d) Delivery, Service, and Support (DSS), domain ini mencakup pelaksanaan, layanan, dan aktivitas pendukung yang dilakukan didalam proses bisnis.

e) Monitoring, Evaluation, and Assess (MEA), domain ini mencakup pemantauan, evaluasi dan penilaian terkait proses-proses yang ada didalam bisnis secara internal maupun eksternal.

C. Proses Pendaftaran Mahasiswa Baru dan Mahasiswa Lulus

Pada alur proses penerimaan mahasiswa baru di STMIK Primakara, data dari mahasiswa baru akan direkap oleh bagian Marketing, kemudian data tersebut akan diserahkan kepada WAKA III Kemahasiswaan. Data ini akan digunakan sebagai acuan dalam merencanakan Pembekalan Mahasiswa Baru (PMB). Setelah PMB terlaksana, data yang ada pada WAKA 
e-ISSN: 2685-7006 | p-ISSN: 2252-9063

III Kemahasiswaan akan diberikan kepada WAKA I Akademik dan WAKA II Keuangan.

Data mahasiswa yang ada pada WAKA I Akademik akan digunakan untuk membuat akun SISKA untuk digunakan oleh mahasiswa baru. Jika mahasiswa belum membayar uang kuliah, akun SISKA tidak bisa dibuat. Maka dari itu, mahasiswa baru harus melakukan pembayaran pada WAKA II Keuangan. Setelahnya, mahasiswa baru tersebut akan mendapatkan akun SISKA yang dapat digunakan untuk mengakses sistem informasi yang ada di STMIK Primakara, seperti SPADA untuk kegiatan pembelajaran, PRILI untuk mengakses perpustakaan digital, POINT untuk merekap data nilai keaktifan mahasiswa dan PRISKA untuk mengakses informasi saat mengambil Tugas Akhir. Setelah mahasiswa melewati ujian tugas akhir dan dinyatakan lulus, maka mahasiswa tersebut telah menyelesaikan studi S1 di STMIK Primakara.

\section{Metode Skala Pengukuran Capability Level}

1. Skala Likert

Dalam mengevaluasi tata Kelola TI yang ada di STMIK Primakara, peneliti akan menggunakan skala likert untuk menghitung data kuantitatif yang peneliti dapatkan dari responden. Data kuantitatif tersebut kemudian akan digunakan peneliti untuk menetapkan skor jawaban dari pertanyaan yang ada disetiap domain proses yang dievaluasi di penelitian ini. Dalam pemberian skor nantinya akan mengikuti ketentuan sebagai berikut:

Tabel 1. Skor Skala Likert

\begin{tabular}{|c|c|c|}
\hline \multirow{2}{*}{ Alternatif } & \multicolumn{2}{|c|}{ Skor } \\
\cline { 2 - 3 } & Positif & Negatif \\
\hline Sangat Setuju & 5 & 1 \\
\hline Setuju & 4 & 2 \\
\hline Ragu-ragu & 3 & 3 \\
\hline Tidak Setuju & 2 & 4 \\
\hline $\begin{array}{c}\text { Sangat Tidak } \\
\text { Setuju }\end{array}$ & 1 & 5 \\
\hline
\end{tabular}

\section{Skala Rating}

Pada framework COBIT 5, peneliti menggunakan skala untuk mengetahui tingkat kemampuan yang dicapai. Atribut peringkat menggunakan skala peringkat standar yang terdiri dari:

1. N (Not Achieved)
Kategori yang menerangkan tidak ada atau hanya sedikit bukti atas pencapaian atribut proses tersebut Range nilai pada kategori ini adalah $0-15 \%$.

2. P (Partially Achieved)

Kategori ini menerangkan adanya beberapa bukti mengenai pendekatan, dan beberapa pencapaian atribut atas proses tersebut. Range nilai pada kategori ini $15-50 \%$.

3. L (Largely Achieved)

Kategori ini menerangkan adanya bukti atas pendekatan sistematis dan pencapaian yang signifikan atas proses tersebut, walau masih terdapat beberapa kelemahan. Range nilai pada kategori ini $50-85 \%$.

4. F (Fully Achieved)

Kategori ini menerangkan adanya pendekatan sistematis dan lengkap serta pencapaian penuh atas atribut proses tersebut. Tidak adanya kelemahan terkait atribut proses tersebut. Range nilai pada kategori ini $85-100 \%$.

Tabel 2. Rating Scale (ISACA, 2013)

\begin{tabular}{|c|l|l|}
\hline Abbreviation & Description & \multicolumn{1}{|c|}{$\%$ Achieved } \\
\hline $\mathrm{N}$ & Not Achieved & $\begin{array}{l}\text { 0 to } 15 \% \\
\text { achievement }\end{array}$ \\
\hline $\mathrm{P}$ & $\begin{array}{l}\text { Partially } \\
\text { Achieved }\end{array}$ & $\begin{array}{l}>15 \% \text { to } 50 \% \\
\text { achievement }\end{array}$ \\
\hline $\mathrm{L}$ & $\begin{array}{l}\text { Largely } \\
\text { Achieved }\end{array}$ & $\begin{array}{l}>50 \% \text { to } 85 \% \\
\text { achievement }\end{array}$ \\
\hline $\mathrm{F}$ & $\begin{array}{l}\text { Fully } \\
\text { Achieved }\end{array}$ & $\begin{array}{l}>85 \% \text { to } 100 \% \\
\text { achievement }\end{array}$ \\
\hline
\end{tabular}

Menurut ISACA. (2012), suatu proses cukup meraih kategori Largely Achieved (L) atau Fully Achieved (F) untuk dapat dinyatakan bahwa proses tersebut telah meraih suatu tingkat kapabilitas tersebut, namun proses tersebut harus meraih kategori Fully Achieved (F) untuk dapat melanjutkan penilaian ke tingkat kapabilitas 3, maka tingkat 1 dan 2 proses tersebut harus mencapai kategori Fully Achieved (F), sementara tingkat 3 kapabilitas cukup mencapai kategori Lagerly Achieved atau Fully Achieved (F).

E. Pengukuran Capability Level menggunakan Skala Likert

Pada buku Surendro (2009) berjudul "Implementasi Tata Kelola TI," terdapat penjelasan mengenai hasil dari perhitungan kuesioner yang direkapitulasi untuk dapat 
merepresentasikan presentase dan Capability level. Maka dapat diuraikan dengan rumus penilaian sebagai berikut:

1. Menghitung Rekapitulasi Jawaban Kuesioner

$$
C=\frac{H}{J R} \times 100 \%
$$

Keterangan:

C : Rekapitulasi jawaban kuesioner Capability Level (dalam bentuk presentase pada masing-masing pilihan jawaban a, b, c, d atau e di masing-masing aktivitas)

$\mathrm{H}$ : Jumlah jawaban kuesioner Capability level pada masing - masing pilihan jawaban level $0,1,2,3$ atau 4 di setiap aktivitas.

JR : Jumlah Responden

2. Menghitung Nilai dan Level Kapabilitas

$N K=\frac{(L P x N k) 0+(L P x N k) 1+(L P x N k) 2+(L P x N k) 3+(L P x N k) 4}{100}$

Keterangan:

NK : Nilai kematangan pada proses TI

LP : Level percentage (tingkat presentase pada setiap distribusi jawaban kuesioner Capability level)

Nk : Nilai kematangan yang tertera pada tabel pemetaan jawaban, nilai dan tingkat kematangan.

Dalam penelitian ini dilakukan perbedaan istilah, yaitu nilai kapabilitas yang memiliki nilai tidak bulat (bilangan desimal), yang merepresentasikan proses pencapaian menuju suatu tingkat kapabilitas tertentu dan tingkat kapabilitas yang lebih menunjukkan kepada tahapan atau kelas yang dicapai dalam proses kapabilitas, yang dinyatakan dalam bilangan bulat (Surendro, 2009).

\section{Metodologi Penelitian}

\section{A. Metode Pengumpulan Data}

Pada penelitian ini, peneliti mengumpulkan data dengan metode kualitatif, yaitu metode yang digunakan untuk memahami fenomena tentang apa yang dialami oleh subjek penelitian misalnya perilaku, persepsi, motivasi, tindakan, dan lain-lain secara holistik dan dengan cara deskripsi dalam bentuk kata-kata dan bahasa pada suatu konteks khusus yang alamiah dan dengan memanfaatkan berbagai metode alamiah. untuk teknik pengumpulan datanya sendiri menggunakan teknik wawancara, survey, studi kepustakaan dan studi dokumen yang dimiliki oleh STMIK Primakara. Dengan demikian, peneliti mendapatkan hasil berupa informasi terkait alur yang harus dilalui mahasiswa saat mulai mendaftar hingga lulus, kemudian peneliti dapat mengetahui kondisi tata kelola TI yang ada di dalam alur tersebut serta ekspektasi dari organisasi ke depannya terkait tata kelola TI di STMIK Primakara

B. Alur Penelitian

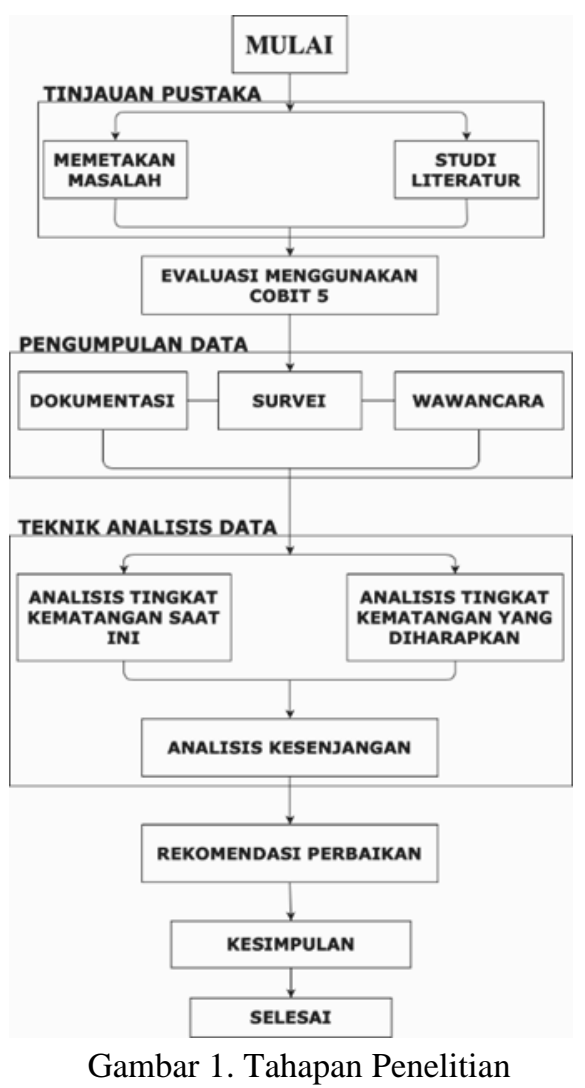

Teknik analisa yang akan dilakukan peneliti adalah dengan pendekatan kualitatif. Adapun tahap yang akan peneliti lakukan agar mendapatkan hasil analisis adalah sebagai berikut:

a. Memetakan Masalah

Dalam tahap ini penulis akan menetapkan permasalahan apa saja yang terdapat pada tata kelola TI di STMIK Primakara sehingga pembahasan tetap berada dalam konteks yang dirumuskan.

b. Melakukan Studi Literatur 
e-ISSN: 2685-7006|p-ISSN: $2252-9063$

Kumpulan Artikel Mahasiswa Pendidikan Teknik Informatika

(KARMAPATI)

Volume 10, Nomor 1, Tahun 2021

\section{KดRMดPดTI}

Dalam studi literatur, penulis akan menggunakan jurnal ilmiah dari penelitian terkait untuk melengkapi data didalam penelitian dan sebagai acuan untuk proses analisa tata kelola TI di STMIK Primakara.

c. Evaluasi Menggunakan COBIT 5

Dengan menggunakan COBIT 5, peneliti akan menganalisa proses tata kelola TI di STMIK Primakara. Proses analisa akan menggunakan domain proses dari COBIT 5 sebagai tools dalam pengumpulan data.

d. Pengumpulan Data

Pengumpulan data dilakukan dengan wawancara, survey, studi kepustakaan, dan studi dokumen.

e. Analisa Data

Analisa data berdasarkan data yang sudah didapatkan melalui metode wawancara, survey, studi kepustakaan, dan studi dokumen. Pengolahan data sampling akan menggunakan SPSS. Kemudian hasil data akan digunakan untuk menentukan maturity level dari tata kelola TI di STMIK Primakara.

\section{Identifikasi Proses TI}

Dalam proses IT yang ada pada COBIT 5 memiliki aktivitas-aktivitas yang merupakan alat kontrol dari proses IT tersebut. Proses IT yang digunakan di dalam penelitian ini telah ditetapkan menggunakan standar COBIT 5 sesuai dengan permasalahan yang ada pada STMIK Primakara terkait dengan tata kelola TI mulai dari mahasiswa masuk dan saat mahasiswa lulus.

Tabel 4. Daftar Proses Teknologi di STMIK Primakara

\begin{tabular}{|c|l|}
\hline Domain Proses & \multicolumn{1}{c|}{ Deskripsi Proses } \\
\hline APO03 & Pengelolaan Arsitektur Enterprise \\
\hline APO04 & Pengelolaan Inovasi \\
\hline BAI01 & Pengelolaan Program dan Proyek \\
\hline
\end{tabular}

\section{Penyusunan Instrumen}

Kuesioner yang menjadi instrumen penelitian ini terdiri dari 25 item pertanyaan yang mengikuti standar pertanyaan dari tools COBIT 5. Pertanyaan-pertanyaan ini disusun khusus untuk responden di STMIK Primakara yang bertanggung jawab untuk tata kelola TI pada bagian pengelolaan arsitektur enterprise, inovasi, program dan proyek.

Kuesioner dalam penelitian ini telah dibuat berdasarkan tools dari COBIT 5 dan telah di konsultasikan kepada ahlinya (judgement expert). Untuk uji validitas, peneliti dibantu oleh dua orang ahli, yakni ahli bahasa dan ahli tata kelola dan audit sistem informasi. Jumlah responden pada penelitian ini adalah 10 orang, terdiri dari Kepala WAKA I Bidang Akademik 1 orang, Pusat Pengembangan Teknologi Informasi (PPTI) 3 orang, WAKA III Bidang Kemahasiswaan 3 orang dan Divisi Marketing 3 orang.

\section{HASIL DAN PEMBAHASAN}

A. Analisis Data

1. APO03 Pengelolaan Arsitektur Enterprise

Tabel 3. Hasil Rekapitulasi Jawaban Kuesioner APO03

\begin{tabular}{|c|c|c|c|c|c|c|c|}
\hline \multirow{2}{*}{ No } & \multirow{2}{*}{$\begin{array}{l}\text { Aktivitas } \\
\text { Proses }\end{array}$} & \multicolumn{6}{|c|}{ Distribusi Jawaban } \\
\hline & & Status & $\mathrm{a}(\%)$ & $\mathrm{b}(\%)$ & $\mathrm{c}(\%)$ & $\mathrm{d}(\%)$ & $\mathrm{e}(\%)$ \\
\hline \multirow{5}{*}{1} & \multirow{5}{*}{$\begin{array}{c}\text { Sejauh mana } \\
\text { Pengelolaan } \\
\text { Aristektur } \\
\text { Enterprise } \\
\text { terkait } \\
\text { dengan } \\
\text { membangun } \\
\text { visi dari } \\
\text { Arsitektur } \\
\text { Enterprise }\end{array}$} & & & & & & \\
\hline & & as is & 0 & 0 & 0 & 100 & 0 \\
\hline & & & & & & & \\
\hline & & & & & & & \\
\hline & & to be & 0 & 0 & 0 & 0 & 100 \\
\hline \multirow{7}{*}{2} & \multirow{7}{*}{$\begin{array}{c}\text { Sejauh mana } \\
\text { Pengelolaan } \\
\text { Aristektur } \\
\text { Enterprise } \\
\text { terkait } \\
\text { dengan } \\
\text { penetapan } \\
\text { Reference } \\
\text { Architecture }\end{array}$} & & & & & & \\
\hline & & & & & & & \\
\hline & & as is & 0 & 0 & 0 & 100 & 0 \\
\hline & & & & & & & \\
\hline & & & & & & & \\
\hline & & to be & 0 & 0 & 0 & 0 & 100 \\
\hline & & & & & & & \\
\hline \multirow{5}{*}{3} & \multirow{5}{*}{$\begin{array}{c}\text { Sejauh mana } \\
\text { Pengelolaan } \\
\text { Aristektur } \\
\text { Enterprise } \\
\text { terkait } \\
\text { dengan } \\
\text { memilih } \\
\text { peluang dan } \\
\text { solusi }\end{array}$} & & & & & & \\
\hline & & as is & 0 & 0 & 100 & 0 & 0 \\
\hline & & & & & & & \\
\hline & & & & & & & \\
\hline & & to be & 0 & 0 & 0 & 0 & 100 \\
\hline \multirow{4}{*}{4} & \multirow{4}{*}{$\begin{array}{c}\text { Sejauh mana } \\
\text { Pengelolaan } \\
\text { Aristektur } \\
\text { Enterprise } \\
\text { terkait } \\
\text { dengan } \\
\text { definisi dari } \\
\text { implementasi } \\
\text { arsitektur }\end{array}$} & & & & & & \\
\hline & & as is & 0 & 0 & 100 & 0 & 0 \\
\hline & & & & & & & \\
\hline & & to be & 0 & 0 & 0 & 0 & 100 \\
\hline
\end{tabular}


Kumpulan Artikel Mahasiswa Pendidikan Teknik Informatika

(KARMAPATI)

Volume 10, Nomor 1, Tahun 2021

KคRMดPดTI

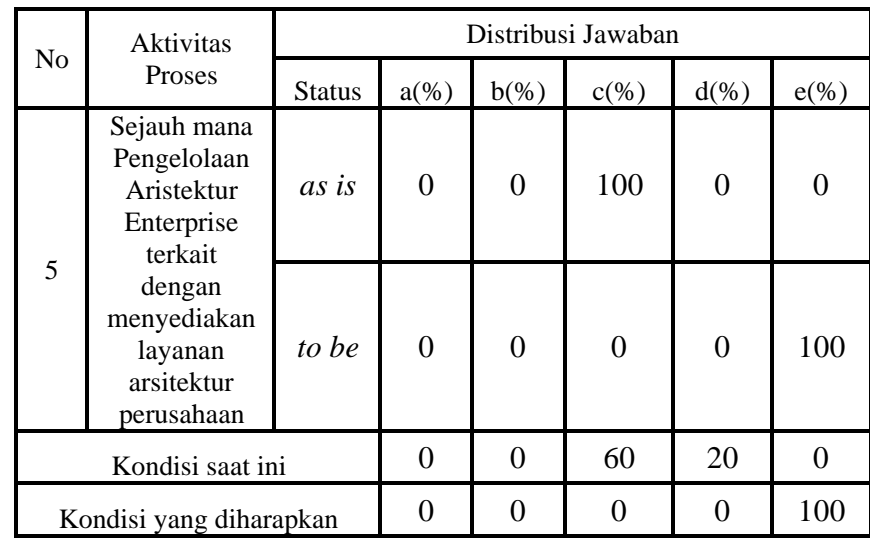

Berdasarkan hasil jawaban kuesioner APO03 dapat disimpulkan bahwa responden menilai kondisi saat ini (as is) dalam evaluasi tata Kelola berada pada jawaban "c" dengan persentase $60 \%$. Sedangkan kondisi yang akan datang (to be), responden berada pada jawaban "e" dengan persentase $100 \%$.

2. APO04 Pengelolaan Inovasi

Tabel 4. Hasil Rekapitulasi Jawaban Kuesioner APO04

\begin{tabular}{|c|c|c|c|c|c|c|c|}
\hline \multirow{2}{*}{ No } & \multirow{2}{*}{$\begin{array}{l}\text { Aktivitas } \\
\text { Proses }\end{array}$} & \multicolumn{6}{|c|}{ Distribusi Jawaban } \\
\hline & & Status & $\mathrm{a}(\%)$ & $\mathrm{b}(\%)$ & $\mathrm{c}(\%)$ & $\mathrm{d}(\%)$ & $\mathrm{e}(\%)$ \\
\hline \multirow{2}{*}{1} & \multirow{2}{*}{$\begin{array}{c}\text { Sejauh mana } \\
\text { Pengelolaan } \\
\text { Inovasi } \\
\text { terkait } \\
\text { dengan } \\
\text { penciptaan } \\
\text { lingkungan } \\
\text { yang } \\
\text { kondusif } \\
\text { untuk } \\
\text { inovasi }\end{array}$} & as is & 0 & 0 & 0 & 100 & 0 \\
\hline & & to be & 0 & 0 & 0 & 0 & 100 \\
\hline \multirow{2}{*}{2} & \multirow{2}{*}{$\begin{array}{c}\text { Sejauh mana } \\
\text { Pengelolaan } \\
\text { Inovasi } \\
\text { terkait } \\
\text { dengan } \\
\text { memelihara } \\
\text { pengertian } \\
\text { dari } \\
\text { lingkungan } \\
\text { enterprise }\end{array}$} & as is & 100 & 0 & 0 & 0 & 0 \\
\hline & & to be & 0 & 0 & 0 & 0 & 100 \\
\hline \multirow{2}{*}{3} & \multirow{2}{*}{$\begin{array}{c}\text { Sejauh mana } \\
\text { Pengelolaan } \\
\text { Inovasi } \\
\text { terkait } \\
\text { dengan } \\
\text { pemantauan } \\
\text { dan } \\
\text { meninjau } \\
\text { lingkungan } \\
\text { teknologi }\end{array}$} & as is & 0 & 0 & 100 & 0 & 0 \\
\hline & & to be & 0 & 0 & 0 & 0 & 100 \\
\hline
\end{tabular}

\begin{tabular}{|c|c|c|c|c|c|c|c|}
\hline \multirow{2}{*}{ No } & \multirow{2}{*}{$\begin{array}{l}\text { Aktivitas } \\
\text { Proses }\end{array}$} & \multicolumn{6}{|c|}{ Distribusi Jawaban } \\
\hline & & Status & $\mathrm{a}(\%)$ & $\mathrm{b}(\%)$ & $\mathrm{c}(\%)$ & $\mathrm{d}(\%)$ & $\mathrm{e}(\%)$ \\
\hline \multirow{2}{*}{4} & \multirow{2}{*}{$\begin{array}{c}\text { Sejauh mana } \\
\text { Pengelolaan } \\
\text { Inovasi } \\
\text { terkait } \\
\text { dengan } \\
\text { penilaian } \\
\text { potensi } \\
\text { teknologi } \\
\text { baru dan } \\
\text { inovasi }\end{array}$} & as is & 0 & 0 & 100 & 0 & 0 \\
\hline & & to be & 0 & 0 & 0 & 0 & 100 \\
\hline \multirow{2}{*}{5} & \multirow{2}{*}{$\begin{array}{l}\text { Sejauh mana } \\
\text { Pengelolaan } \\
\text { Inovasi } \\
\text { terkait } \\
\text { dengan } \\
\text { rekomendasi } \\
\text { inisiatif lebih } \\
\text { lanjut } \\
\text { yang sesuai }\end{array}$} & as is & 0 & 0 & 100 & 0 & 0 \\
\hline & & to be & 0 & 0 & 0 & 0 & 100 \\
\hline \multirow{2}{*}{6} & \multirow{2}{*}{$\begin{array}{c}\text { Sejauh mana } \\
\text { Pengelolaan } \\
\text { Inovasi } \\
\text { terkait } \\
\text { dengan } \\
\text { memonitor } \\
\text { implementasi } \\
\text { dan } \\
\text { penggunaan } \\
\text { inovasi }\end{array}$} & as is & 0 & 0 & 100 & 0 & 0 \\
\hline & & to be & 0 & 0 & 0 & 0 & 100 \\
\hline \multicolumn{3}{|c|}{ Kondisi saat ini } & 16.66 & 0 & 83.33 & 0 & 0 \\
\hline \multicolumn{3}{|c|}{ Kondisi yang diharapkan } & 0 & 0 & 0 & 0 & 100 \\
\hline
\end{tabular}

Berdasarkan hasil jawaban kuesioner APO04 dapat disimpulkan bahwa responden menilai kondisi saat ini (as is) dalam evaluasi tata Kelola berada pada jawaban "c" dengan persentase $83.33 \%$. Sedangkan kondisi yang akan datang (to be), responden berada pada jawaban "e" persentase $100 \%$.

3. BAI01 Pengelolaan Program dan Proyek Tabel 5. Hasil Rekapitulasi Jawaban Kuesioner BAI01

\begin{tabular}{|c|c|c|c|c|c|c|c|}
\hline \multirow{2}{*}{1} & No & Aktivitas Proses & \multicolumn{5}{|c|}{ Distribusi Jawaban } \\
\cline { 3 - 7 } & $\begin{array}{c}\text { Sejauh mana } \\
\text { Pengelolaan } \\
\text { Program dan } \\
\text { Proyek terkait } \\
\text { dengan } \\
\text { memelihara } \\
\text { standar } \\
\text { pendekatan } \\
\text { untuk program }\end{array}$ & as is & 0 & 0 & 0 & 100 & 0 \\
\cline { 3 - 8 } & to be & 0 & 0 & 0 & 0 & 100 \\
\hline
\end{tabular}


e-ISSN: 2685-7006 | p-ISSN: $2252-9063$

Kumpulan Artikel Mahasiswa Pendidikan Teknik Informatika

(KARMAPATI)

Volume 10, Nomor 1, Tahun 2021

KดRMAPคTI

\begin{tabular}{|c|c|c|c|c|c|c|c|}
\hline \multirow{3}{*}{ No } & \multirow{3}{*}{$\begin{array}{l}\text { Aktivitas Proses } \\
\text { dan } \\
\text { manajemen } \\
\text { proyek }\end{array}$} & \multicolumn{6}{|c|}{ Distribusi Jawaban } \\
\hline & & Status & $\mathrm{a}(\%)$ & $\mathrm{b}(\%)$ & $\mathrm{c}(\%)$ & $\mathrm{d}(\%)$ & $\mathrm{e}(\%)$ \\
\hline & & & & & & & \\
\hline \multirow[b]{2}{*}{2} & \multirow{2}{*}{$\begin{array}{c}\text { Sejauh mana } \\
\text { Pengelolaan } \\
\text { Program dan } \\
\text { Proyek terkait } \\
\text { dengan inisiasi } \\
\text { program }\end{array}$} & as is & 0 & 0 & 100 & 0 & 0 \\
\hline & & to be & 0 & 0 & 0 & 0 & 100 \\
\hline \multirow[b]{2}{*}{3} & \multirow{2}{*}{$\begin{array}{c}\text { Sejauh mana } \\
\text { Pengelolaan } \\
\text { Program dan } \\
\text { Proyek terkait } \\
\text { dengan } \\
\text { mengelola } \\
\text { keterlibatan } \\
\text { stakeholder }\end{array}$} & as is & 0 & 0 & 100 & 0 & 0 \\
\hline & & to be & 0 & 0 & 100 & 0 & 0 \\
\hline \multirow[b]{2}{*}{4} & \multirow{2}{*}{$\begin{array}{c}\text { Sejauh mana } \\
\text { Pengelolaan } \\
\text { Program dan } \\
\text { Proyek terkait } \\
\text { dengan } \\
\text { mengembangkan } \\
\text { dan memelihara } \\
\text { rencana program }\end{array}$} & as is & 0 & 0 & 0 & 0 & 100 \\
\hline & & to be & 0 & 0 & 100 & 0 & 0 \\
\hline \multirow[b]{2}{*}{5} & \multirow{2}{*}{$\begin{array}{c}\text { Sejauh mana } \\
\text { Pengelolaan } \\
\text { Program dan } \\
\text { Proyek terkait } \\
\text { dengan } \\
\text { meluncurkan } \\
\text { dan } \\
\text { mengeksekusi } \\
\text { program } \\
\end{array}$} & as is & 0 & 0 & 0 & 100 & 0 \\
\hline & & to be & 0 & 0 & 0 & 0 & 100 \\
\hline \multirow{2}{*}{6} & \multirow{2}{*}{$\begin{array}{c}\text { Sejauh mana } \\
\text { Pengelolaan } \\
\text { Program dan } \\
\text { Proyek terkait } \\
\text { dengan monitor, } \\
\text { kontrol dan } \\
\text { melaporkan } \\
\text { hasil } \\
\text { dari program } \\
\end{array}$} & as is & 0 & 0 & 100 & 0 & 0 \\
\hline & & to be & 0 & 0 & 0 & 0 & 100 \\
\hline \multirow[b]{2}{*}{7} & \multirow{2}{*}{$\begin{array}{c}\text { Sejauh mana } \\
\text { Pengelolaan } \\
\text { Program dan } \\
\text { Proyek terkait } \\
\text { dengan memulai } \\
\text { dan menginisiasi } \\
\text { proyek dalam } \\
\text { program }\end{array}$} & as is & 0 & 0 & 100 & 0 & 0 \\
\hline & & to be & 0 & 0 & 0 & 0 & 100 \\
\hline 8 & $\begin{array}{l}\text { Sejauh mana } \\
\text { Pengelolaan } \\
\text { Program dan }\end{array}$ & as is & 0 & 0 & 0 & 100 & 0 \\
\hline
\end{tabular}

\begin{tabular}{|c|c|c|c|c|c|c|c|}
\hline \multirow{3}{*}{ No } & \multirow{3}{*}{$\begin{array}{l}\text { Aktivitas Proses } \\
\text { Proyek terkait } \\
\text { dengan } \\
\text { merencanakan } \\
\text { proyek }\end{array}$} & \multicolumn{6}{|c|}{ Distribusi Jawaban } \\
\hline & & Status & $\mathrm{a}(\%)$ & $\mathrm{b}(\%)$ & $\mathrm{c}(\%)$ & $\mathrm{d}(\%)$ & $\mathrm{e}(\%)$ \\
\hline & & to be & 0 & 0 & 0 & 0 & 100 \\
\hline \multirow[b]{2}{*}{9} & \multirow{2}{*}{$\begin{array}{c}\text { Sejauh mana } \\
\text { Pengelolaan } \\
\text { Program dan } \\
\text { Proyek terkait } \\
\text { dengan } \\
\text { mengelola } \\
\text { program dan } \\
\text { kualitas proyek }\end{array}$} & as is & 0 & 0 & 100 & 0 & 0 \\
\hline & & to be & 0 & 0 & 0 & 0 & 100 \\
\hline \multirow[b]{2}{*}{10} & \multirow{2}{*}{$\begin{array}{c}\text { Sejauh mana } \\
\text { Pengelolaan } \\
\text { Program dan } \\
\text { Proyek terkait } \\
\text { dengan } \\
\text { mengelola } \\
\text { program dan } \\
\text { risiko } \\
\text { proyek }\end{array}$} & as is & 0 & 0 & 0 & 100 & 0 \\
\hline & & to be & 0 & 0 & 0 & 0 & 100 \\
\hline \multirow[b]{2}{*}{11} & \multirow{2}{*}{$\begin{array}{c}\text { Sejauh mana } \\
\text { Pengelolaan } \\
\text { Program dan } \\
\text { Proyek terkait } \\
\text { dengan } \\
\text { memonitor dan } \\
\text { mengontrol } \\
\text { proyek }\end{array}$} & as is & 0 & 0 & 100 & 0 & 0 \\
\hline & & to be & 0 & 0 & 0 & 0 & 100 \\
\hline \multirow[b]{2}{*}{12} & \multirow{2}{*}{$\begin{array}{c}\text { Sejauh mana } \\
\text { Pengelolaan } \\
\text { Program dan } \\
\text { Proyek terkait } \\
\text { dengan } \\
\text { pengelolaan } \\
\text { sumber daya } \\
\text { proyek dan } \\
\text { paket } \\
\text { pekerjaan }\end{array}$} & as is & 0 & 0 & 100 & 0 & 0 \\
\hline & & to be & 0 & 0 & 0 & 0 & 100 \\
\hline \multirow[b]{2}{*}{13} & \multirow{2}{*}{$\begin{array}{l}\text { Sejauh mana } \\
\text { Pengelolaan } \\
\text { Program dan } \\
\text { Proyek terkait } \\
\text { dengan } \\
\text { penutupan } \\
\text { proyek dan } \\
\text { iterasi }\end{array}$} & as is & 0 & 0 & 100 & 0 & 0 \\
\hline & & to be & 0 & 0 & 0 & 0 & 100 \\
\hline \multirow[b]{2}{*}{14} & \multirow{2}{*}{$\begin{array}{c}\text { Sejauh mana } \\
\text { Pengelolaan } \\
\text { Program dan } \\
\text { Proyek terkait } \\
\text { dengan } \\
\text { penutupan } \\
\text { program }\end{array}$} & as is & 100 & 0 & 0 & 0 & 0 \\
\hline & & to be & 0 & 0 & 0 & 0 & 100 \\
\hline \multicolumn{3}{|c|}{ Kondisi saat ini } & 7.12 & 0 & 64.28 & 28.57 & 0 \\
\hline \multicolumn{3}{|c|}{ Kondisi yang diharapkan } & 0 & 0 & 0 & 0 & 100 \\
\hline
\end{tabular}




\section{KดRMAPคTI}

Berdasarkan hasil jawaban kuesioner BAI01 dapat disimpulkan bahwa responden menilai kondisi saat ini (as is) dalam evaluasi tata Kelola berada pada jawaban "c" dengan persentase $64.28 \%$. Sedangkan kondisi yang akan datang (to be), responden berada pada jawaban "e" dengan persentase $100 \%$.

B. Penentuan Nilai dan Tingkat Kapabilitas

1. Nilai Kapabilitas APO03 Pengelolaan Arsitektur Enterprise

$$
\begin{aligned}
& \text { As is APO03 } \\
& \begin{aligned}
N K & =\frac{(0 \times 0)+(0 \times 1)+(60 \times 2)+(20 \times 3)+(0 \times 4)}{100} \\
\quad & =1.8
\end{aligned} \\
& \text { To be APO03 } \\
& \begin{aligned}
N K & =\frac{(0 \times 0)+(0 \times 1)+(0 \times 2)+(0 \times 3)+(100 \times 4)}{100} \\
\quad & =4
\end{aligned}
\end{aligned}
$$

Berdasarkan perhitungan di atas, maka dapat disimpulkan bahwa keadaan saat ini pada STMIK Primakara untuk mengevaluasi sistem tata kelola memiliki nilai kapabilitas 1.8 yaitu berada pada tingkat kapabilitas 2 , sedangkan kondisi yang diharapkan memiliki nilai kapabilitas 4, dengan kata lain berada pada tingkat kapabilitas 4 .

2. Nilai Kapabilitas APO04 Pengelolaan Inovasi

$$
\begin{aligned}
& \text { As is APO04 } \\
& \begin{aligned}
N K & =\frac{(16.66 \times 0)+(0 \times 1)+(83.33 \times 2)+(0 \times 3)+(0 \times 4)}{100} \\
& =1.6666
\end{aligned} \\
& \text { To be APO04 } \\
& \begin{aligned}
N K & =\frac{(0 \times 0)+(0 \times 1)+(0 \times 2)+(0 \times 3)+(100 \times 4)}{100} \\
& =4
\end{aligned}
\end{aligned}
$$

Berdasarkan perhitungan di atas, maka dapat disimpulkan bahwa keadaan saat ini pada STMIK Primakara untuk mengevaluasi sistem tata kelola memiliki kapabilitas 1.6666 yaitu berada pada tingkat kapabilitas 2, sedangkan kondisi yang diharapkan memiliki nilai kapabilitas 4, dengan kata lain berada pada tingkat kapabilitas 4 .

3. Nilai Kapabilitas BAI01 Pengelolaan Program dan Proyek

As is $\mathrm{BAI} 01$

$$
\begin{aligned}
& \begin{array}{l}
N K= \\
=2.1427 \\
\text { To be BAI01 } \\
\quad N K=\frac{(0 \times 0)+(0 \times 1)+(0 \times 2)+(0 \times 3)+(100 \times 4)}{100} \\
\quad=4
\end{array}
\end{aligned}
$$

Berdasarkan perhitungan di atas, maka dapat disimpulkan bahwa keadaan saat ini pada STMIK Primakara untuk mengevaluasi sistem tata kelola memiliki kapabilitas 2.1427 yaitu berada pada tingkat kapabilitas 2, sedangkan kondisi yang diharapkan memiliki nilai kapabilitas 4, dengan kata lain berada pada tingkat kapabilitas 4 .

\section{Gap dan Rekomendasi}

Berdasarkan hasil evaluasi yang telah dilakukan di STMIK Primakara, peneliti menggabungkan temuan yang didapatkan dari studi dokumen dan wawancara kepada responden terkait untuk menjelaskan gap yang ada dari tingkat kapabilitas saat ini dan tingkat kapabilitas yang diinginkan. Adapun hasil dari setiap proses tertera pada tabel di bawah ini.

1. Proses APO03

Dapat dilihat dari gambar 4.3 bahwa proses APO03 (Align, Plan and Organize Manage Enterprise Architecture), memiliki performa dengan nilai 1.8 dan untuk tingkat kapabilitasnya berada pada level 2 . Berikut dibawah ini adalah hasil dari penelitian gap dan rekomendasi terkait evaluasi tata kelola TI di STMIK Primakara dengan menggunakan domain proses APO03. 
e-ISSN: 2685-7006 | p-ISSN: $2252-9063$

Kumpulan Artikel Mahasiswa Pendidikan Teknik Informatika

(KARMAPATI)

Volume 10, Nomor 1, Tahun 2021

KคRMAPคTI

di STMIK Primakara dengan menggunakan domain proses APO04.

Tabel 6. Proses APO03

\begin{tabular}{|c|c|c|c|}
\hline Proses & Temuan & GAP & Rekomendasi \\
\hline $\begin{array}{l}\text { APO03 } \\
\text { Pengelolaan } \\
\text { Arsitektur } \\
\text { Enterprise }\end{array}$ & $\begin{array}{l}\text { 1. Dalam } \\
\text { pembangunan } \\
\text { arsitektur } \\
\text { enterprise, } \\
\text { sistem } \\
\text { dibuat oleh } \\
\text { PPTI dan untuk } \\
\text { jaringannya } \\
\text { sendiri dibuat } \\
\text { oleh } \\
\text { vendor } \\
\text { eksternal (ISP). } \\
\text { 2. Arsitektur } \\
\text { Enterprise } \\
\text { dikelola oleh } \\
\text { PPTI dengan } \\
\text { mengekstrak } \\
\text { butir-butir } \\
\text { terkait di dalam } \\
\text { renstra, lalu } \\
\text { dituangkan } \\
\text { kembali di } \\
\text { masterplan IT } \\
\text { di STMIK } \\
\text { Primakara } \\
\text { Periode } \\
\text { 2019/2023. } \\
\text { Masterplan IT } \\
\text { ini menjadi } \\
\text { pedoman } \\
\text { dalam } \\
\text { pengelolaan } \\
\text { dan } \\
\text { pengembangan } \\
\text { teknologi } \\
\text { informasi } \\
\text { untuk } \\
\text { perkembangan } \\
\text { STMIK } \\
\text { Primakara dan } \\
\text { lingkungan } \\
\text { strategisnya. }\end{array}$ & $\begin{array}{l}\text { 1. Di dalam } \\
\text { masterplan } \\
\text { terkait } \\
\text { pengelolaan } \\
\text { arsitektur } \\
\text { enterprise, } \\
\text { PPTI telah } \\
\text { membuat } \\
\text { roadmap } \\
\text { serta program } \\
\text { kerja } \\
\text { masterplan } \\
\text { terkait } \\
\text { dengan } \\
\text { pengelolaan } \\
\text { arsitektur } \\
\text { enterprise. } \\
\text { Arsitektur } \\
\text { enterprise ini } \\
\text { dibagi ke } \\
\text { dalam dua } \\
\text { kelompok } \\
\text { Area } \\
\text { fungsional, } \\
\text { antara lain } \\
\text { aktifitas } \\
\text { utama dan } \\
\text { aktifitas } \\
\text { pendukung. } \\
\text { Namun, PPTI } \\
\text { belum dapat } \\
\text { memaksimal } \\
\text { kan } \\
\text { pengelolaan } \\
\text { arsitektur } \\
\text { enterprise } \\
\text { dikarenakan } \\
\text { banyaknya } \\
\text { sistem yang } \\
\text { harus dibuat } \\
\text { untuk } \\
\text { mendukung } \\
\text { aktifitas } \\
\text { utama dan } \\
\text { aktifitas } \\
\text { pendukung. }\end{array}$ & $\begin{array}{l}\text { 1. Perlunya } \\
\text { diberikan } \\
\text { prioritas terkait } \\
\text { pembuatan } \\
\text { sistem atau } \\
\text { berikan PPTI } \\
\text { untuk } \\
\text { mengerjakan } \\
\text { sistem untuk } \\
\text { mendukung } \\
\text { aktifitas utama } \\
\text { secara } \\
\text { maksimal. } \\
\text { Sehingga di } \\
\text { saat aktifitas } \\
\text { utama sudah } \\
\text { berjalan dengan } \\
\text { lancar, PPTI } \\
\text { dapat berfokus } \\
\text { kepada } \\
\text { pembuatan } \\
\text { sistem untuk } \\
\text { aktifitas } \\
\text { pendukung. } \\
\text { 2. Perlu } \\
\text { ditambahnya } \\
\text { sumber daya } \\
\text { pada bagian } \\
\text { PPTI agar dapat } \\
\text { membantu terkait } \\
\text { dengan } \\
\text { pembuatan } \\
\text { sistem. }\end{array}$ \\
\hline
\end{tabular}

Tabel 7. Proses APO04

\begin{tabular}{|c|c|c|c|}
\hline Proses & Temuan & GAP & Rekomendasi \\
\hline $\begin{array}{l}\text { APO04 } \\
\text { Pengelo } \\
\text { laan } \\
\text { Inovasi }\end{array}$ & $\begin{array}{l}\text { Dalam } \\
\text { pengelolaan } \\
\text { inovasi, PPTI } \\
\text { menggunakan } \\
\text { masterplan } \\
\text { sebagai } \\
\text { dokumen } \\
\text { acuan untuk } \\
\text { menciptakan } \\
\text { lingkungan } \\
\text { yang kondusif } \\
\text { untuk inovasi. }\end{array}$ & $\begin{array}{l}\text { 1. Di dalam } \\
\text { masterplan, } \\
\text { rancangan } \\
\text { blueprint sistem } \\
\text { informasi yang } \\
\text { Mengatur alur } \\
\text { penerimaan } \\
\text { mahasiswa baru } \\
\text { hingga } \\
\text { mahasiswa } \\
\text { lulus telah } \\
\text { ada. Akan } \\
\text { tetapi, detail } \\
\text { dari proses yang } \\
\text { ada pada } \\
\text { masterplan IT } \\
\text { STMIK } \\
\text { Primakara tidak } \\
\text { menyeluruh } \\
\text { sehingga } \\
\text { informasi yang } \\
\text { ada di dalam } \\
\text { masterplan } \\
\text { tidak lengkap. } \\
\text { 2.Pemantauan } \\
\text { serta peninjauan } \\
\text { lingkungan } \\
\text { inovasi didalam } \\
\text { PPTI adalah } \\
\text { PPM namun } \\
\text { tidak ada } \\
\text { dokumen } \\
\text { khusus terkait } \\
\text { peninjauan } \\
\text { lingkungan } \\
\text { inovasi yang } \\
\text { ada di } \\
\text { dalam PPTI. }\end{array}$ & $\begin{array}{l}\text { 1. Melengkapi } \\
\text { detail dari } \\
\text { proses } \\
\text { rancangan yang } \\
\text { ada di dalam } \\
\text { masterplan. } \\
\text { 2. Membuat } \\
\text { dokumen } \\
\text { khusus } \\
\text { pemantauan } \\
\text { serta peninjauan } \\
\text { inovasi yang } \\
\text { berada di } \\
\text { lingkungan } \\
\text { PPTI sehingga } \\
\text { nantinya } \\
\text { dokumen } \\
\text { tersebut dapat } \\
\text { dijadikan tolak } \\
\text { ukur } \\
\text { pengelolaan } \\
\text { inovasi yang } \\
\text { ada di PPTI. }\end{array}$ \\
\hline
\end{tabular}

\section{Proses APO04}

Dapat dilihat dari gambar 4.3 bahwa proses APO04 (Align, Plan and Organize Manage Innovation), memiliki performa dengan nilai 1.6666 dan untuk tingkat kapabilitasnya berada pada level 2. Berikut dibawah ini adalah hasil dari penelitian gap dan rekomendasi terkait evaluasi tata kelola TI

\section{Proses BAI01}

Dapat dilihat dari gambar 4.3 bahwa proses BAI01 (Build, Acquire, Operate Manage Programmes and Projects), memiliki performa dengan nilai 2.1247 dan untuk tingkat kapabilitasnya berada pada level 2. Berikut dibawah ini adalah hasil dari penelitian gap dan rekomendasi terkait 
e-ISSN: 2685-7006|p-ISSN: $2252-9063$

Kumpulan Artikel Mahasiswa Pendidikan Teknik Informatika

(KARMAPATI)

Volume 10, Nomor 1, Tahun 2021

KดRMAPดTI

evaluasi tata kelola TI di STMIK Primakara dengan menggunakan domain proses BAI01.

Tabel 8. Proses BAI01

\begin{tabular}{|c|c|c|c|}
\hline Proses & Temuan & GAP & Rekomendasi \\
\hline $\begin{array}{l}\text { BAI01 } \\
\text { Pengelolaan } \\
\text { Program dan } \\
\text { Proyek }\end{array}$ & $\begin{array}{l}\text { Dalam } \\
\text { pengelolaan } \\
\text { program dan } \\
\text { proyek, PPTI } \\
\text { menggunakan } \\
\text { masterplan } \\
\text { sebagai } \\
\text { dokumen } \\
\text { acuan dalam } \\
\text { inisiasi, } \\
\text { pengembanga } \\
\text { n, peluncuran, } \\
\text { monitoring, } \\
\text { perencanaan, } \\
\text { dan } \\
\text { penutupan } \\
\text { program dan } \\
\text { proyek } \\
\text { terkait. }\end{array}$ & $\begin{array}{l}\text { Dalam } \\
\text { pengelolaan } \\
\text { keterlibatan } \\
\text { stakeholders, } \\
\text { pengembangan } \\
\text { dan } \\
\text { pemeliharan } \\
\text { rencana } \\
\text { program belum } \\
\text { memiliki } \\
\text { dokumen yang } \\
\text { mengatur hal } \\
\text { tersebut. } \\
\text { Selama ini, } \\
\text { keterlibatan } \\
\text { stakeholders } \\
\text { dalam suatu } \\
\text { program dan } \\
\text { proyek, dapat } \\
\text { dilihat dalam } \\
\text { RKA tahunan. }\end{array}$ & $\begin{array}{l}\text { Dalam pengelolaan } \\
\text { program dan proyek, } \\
\text { sekiranya PPTI harus } \\
\text { mengajukan } \\
\text { penambahan sumber } \\
\text { daya } \\
\text { Manusia di dalam } \\
\text { pengelolaan program } \\
\text { dan proyek tersebut, } \\
\text { karena dari RKAT } \\
\text { 2019/2020 } \\
\text { Terdapat } 28 \text { rencana } \\
\text { kerja yang ada dan itu } \\
\text { semua harus dikelola } \\
\text { oleh PPTI yang hanya } \\
\text { beranggotakan } \\
3 \text { orang. }\end{array}$ \\
\hline
\end{tabular}

\section{PENUTUP}

Penelitian ini dilakukan untuk mengevaluasi tata kelola TI di kampus STMIK Primakara menggunakan framework COBIT 5. Proses yang diteliti adalah proses tata kelola TI yang ada di STMIK Primakara mulai dari penerimaan mahasiswa baru hingga mahasiswa lulus. Di dalam proses ini, yang melakukan tata kelola terkait teknologi informasi di STMIK Primakara adalah bagian Pengembangan dan Penerapan Teknologi Informasi (PPTI). Berdasarkan dari hasil pembahasan pada evaluasi Tata Kelola TI menggunakan framework COBIT 5 dengan studi kasus STMIK Primakara, dapat disimpulkan bahwa:

1. Pelaksanaan tata kelola TI saat mahasiswa mulai masuk hingga mahasiswa lulus, yang meliputi domain APO03, APO04, dan BAI01 telah dilakukan dengan baik.

2. Tingkat kapabilitas saat ini berada pada level Partially Achieved, yaitu berkisar di nilai pencapaian sebesar $50 \%$.

3. Diperlukan pengembangan dokumen-dokumen terkait domain proses yang diteliti serta peningkatan jumlah sumber daya yang mengelola teknologi informasi di STMIK Primakara.

\section{REFERENSI}

[1] Haag, S and Keen P., "Information Technology, Tomorrow's Advantage Today." McGraw-Hill, 1996.

[2] ITGID | IT Governance Indonesia. "Kupas Tuntas Tata Kelola IT (IT Governance)." Diakses pada tanggal 21 Juli 2019, https://itgid.org/kupas-tuntas-tata- kelola-it-it-governance/

[3] Cynthia Octaria, "Audit Tata Kelola Teknologi Informasi di Universitas Lampung Menggunakan Framework COBIT 5 Fokus Domain EDM (Evaluate, Direct, and Monitor)," Lampung: Universitas Lampung, 2017.

[4] I Gusti Lanang Agung Raditya, dan I Wayan Diana Putra Adnyana "Evaluasi Tata kelola Sistem Informasi Akademik Stmik Primakara Menggunakan Framework Cobit 5." Jurnal Teknologi Informasi Dan Komputer, vol. 5, no. 1, 2019, doi:10.36002/jutik.v5i1.636

[5] ISACA, "COBIT 5 A Business Framework for the Governance and Management of Enterprise IT," USA: ISACA, 2012.

[6] Tri Rahayu, Nurhafifah Matondang, dan Bayu Hananto, "Audit Sistem Informasi Akademik Menggunakan Metode Cobit 5 (studi kasus UPN Veteran Jakarta)," Jakarta: UPN Veteran, 2020.

[7] Hilmawan, Hadi, et al. "Analisis Tata Kelola Teknologi Informasi Menggunakan Kerangka Kerja COBIT 5 Pada AMIK JTC Semarang." Jurnal Teknologi Dan Sistem Komputer, vol. 3, no. 2, 2015, p. 247. doi:10.14710/jtsiskom.3.2.2015.247-252.

[8] Asriyanik dan Mokhamad Hendayun. "Tata Kelola Pada Perguruan Tinggi Menggunakan Control Objective for Information dan Related Technology (COBIT) 5." Jurnal Teknik Informatika Dan Sistem Informasi, vol. 3, no. 1, 2017, doi:10.28932/jutisi.v3i1.597.

[9] Teguh Pribadi dkk, "Evaluasi Pengelolaan Strategi dan Pengelolaan Hubungan dalam Implementasi Teknologi Informasi Menggunakan COBIT5 pada Badan Perencanaan Pembangunan, Penelitian, dan Pengembangan Daerah Kota Batu," Malang: Universitas Brawijaya, 2019.

[10] Steven Lolong dan Dipta Divakara Pius Purwadaria, "Analisis Efektivitas Sistem Informasi Perpustakaan Menggunakan COBIT 5 di Universitas Klabat,” Airmadidi: Universitas Klabat, 2017. 